\title{
Classification of intra-abdominal adhesions after cesarean delivery
}

\author{
Togas Tulandi • Deirdre J. Lyell
}

Received: 5 July 2012 / Accepted: 16 August 2012 /Published online: 2 September 2012

(C) Springer-Verlag 2012

\begin{abstract}
The objective of the study was to develop a standard classification for adhesions after cesarean delivery. We searched the Medline, Pubmed, EMBASE, and the Cochrane database of systematic reviews from 1996 through 2011 for all articles pertaining to adhesion scoring after a cesarean delivery. We performed the search using the keywords "cesarean, adhesions, repeat cesarean, intra-abdominal adhesions, adhesion scoring system, and adhesion classification.” Most published adhesion scoring systems were non-site-specific or unclearly described. The most comprehensive adhesion scoring systems were described in three prospective studies that came from two institutions. The scoring systems were similar, site-specific, involving over four sites, and assessing the severity and consistency of adhesions. We combined the two scoring systems to develop a standardized classification of adhesions after cesarean delivery. To date, there are no uniform classifications of intra-abdominal adhesions after cesarean delivery. We hereby outline the first standardized classification of adhesions after cesarean delivery.
\end{abstract}

Keywords Adhesion · Cesarean · Classification · Scoring system

\section{Background}

Cesarean delivery is one of the most common operations performed on women, and its rate keeps increasing. The

T. Tulandi $(\bowtie)$

Department of Obstetrics and Gynecology, McGill University, 687 Pine Ave. West,

Montreal, Quebec H3A 1A1, Canada

e-mail: togas.tulandi@mcgill.ca

D. J. Lyell

Department of Obstetrics and Gynecology, Stanford University, Stanford, CA, USA rates of cesarean in the USA in 1996 and 2009 were 20.7 and $32.9 \%$ respectively, an increase of over $50 \%[1,2]$. In the states of Louisiana and New Jersey, the rates were close to $40 \%$. The increasing rate of cesarean deliveries can be attributed to many factors including an increased repeat cesarean delivery rate. The repeat cesarean delivery rate among all live births was $6.7 \%$ in 1996 and $14.8 \%$ in 2001, representing an increase of over $120 \%$. [3]. Martin et al. reported that the repeat cesarean delivery rate increased from 69.8 in 1996 to 88.7 in 2003 per 100 births among low-risk women with a previous cesarean [2].

Adhesions develop frequently following cesarean delivery, with estimates of adhesions following the first cesarean ranging from $24.4 \%$ overall [4] to $73 \%$ when the parietal peritoneum is left open [5]. Several studies have demonstrated that adhesions develop more frequently and with greater density with each repeat cesarean and are associated with increasing maternal morbidity [4, 6-8].

In studies of post-cesarean adhesions, however, each institution has used a different adhesion-grading system and approach, which may explain the significant variation in reporting. In the field of infertility, the classification of adnexal adhesions of the American Society for Reproductive Medicine has been widely used clinically and for research purposes [9]. Yet, to date, there has been no standardization of adhesions after cesarean delivery. Indeed, there is a paucity of information about adhesions in obstetric settings, and its consequences have been underappreciated [10].

The purpose of our literature review is to develop a standard classification for adhesions after cesarean delivery.

\section{Materials and methods}

We searched Medline, EMBASE, Pubmed, and the Cochrane database of systematic reviews from 1996 through 2011 for all articles pertaining to adhesion scoring after a 
cesarean delivery. We performed the search using the keywords "cesarean, adhesions, repeat cesarean, intra-abdominal adhesions, adhesion scoring system, and adhesion classification". We reviewed reference lists from any identified article including reviews to find other publications.

\section{Study selection}

We examined all articles that studied adhesions after cesarean deliveries and the outcome. Those with adhesion scoring systems or classifications of adhesions were evaluated for whether scoring was performed prospectively and whether it was site-specific. We included studies where the adhesions were evaluated prospectively with site-specific adhesion scoring systems (Table 1) [5, 11, 12]. Studies with unclear evaluation of adhesions (Table 2) [13-18] and retrospective studies (Tables 3 and 4) [19-25] were excluded.

\section{Findings}

Besides studies listed on Table 1, all adhesion scoring systems were non-site-specific or unclearly described [13-18]. There were three randomized studies (Table 2). Roset et al. evaluated a subgroup of patients involved in a previous randomized trial; adhesions were evaluated retrospectively [13]. Weerawetwat et al. used an adhesion scoring system (no adhesions, mild, moderate, and severe adhesions) based on the width of the adhesion bands and described whether the adhesions involved the uterus, bladder, omentum, or abdominal wall [14]. The study lacks detailed description of site-specific adhesions. Another randomized study [18] used a different grading of adhesions based on the ease of removal of adhesion bands between the uterus and omentum or rectus muscle. The study involved a small number of cases.

Of three prospective non-randomized studies, Salim et al. used a site-specific adhesion scoring system, and severity of adhesions was divided into light filmy or dense vascular adhesions [16]. However, detailed description of sitespecific adhesions was not provided. Komoto et al. evaluated the frequency of adhesions but not the severity [15]. Malvasi et al. evaluated adhesions in limited locations, primarily between the bladder and the uterus, and severity of adhesions was graded as none, mild, or severe [17].

The most comprehensive adhesion scoring systems were described in three prospective studies (Table 1). Although they came from two institutions, the scoring systems were similar, site-specific involving over four sites, and assessed the severity and consistency of adhesions. The validity of the two scoring systems was evaluated by each institution, with inter-rater reliability of 0.85 and 0.84 , respectively. As a result, we combined the two scoring systems (Table 5). In this new classification, we use a point system, and the scores from multiple sites are additive. The area of incision covered by adhesions is divided into $<3 \mathrm{~cm}, 3-6 \mathrm{~cm}$, and $>6 \mathrm{~cm}$. This is based on the estimate that in general, the length of incision for cesarean delivery is approximately $10 \mathrm{~cm}$. Three centimeters is about one third of the incision length and $6 \mathrm{~cm}$ is approximately two third of the length.

\section{Comment}

There have been many studies evaluating adhesion formation after cesarean delivery, mainly comparing the effects of peritoneal closure and non-closure. Due to the increasing number of repeat cesarean deliveries, several authors have started to examine the effects of repeated cesareans on adhesion formation.

To date, there has never been a uniform classification of intra-abdominal adhesions after cesarean delivery. Previous studies have used either no adhesion scoring system or a non-site-specific scoring system [19-25]. For example, Chapa et al. graded the adhesions as no adhesions (grade 0), minimal or filmy adhesions (grade 1), moderate/thick adhesions (grade 2), and absence of free space between the uterus and anterior abdominal wall/viscera [25]. The system does not

Table 1 Prospective studies with site-specific adhesion scoring system

\begin{tabular}{|c|c|c|c|c|c|}
\hline Authors & Type of study & Main outcome measures & $\begin{array}{l}\text { Number of } \\
\text { patients } \\
\text { analyzed }\end{array}$ & $\begin{array}{l}\text { Number of } \\
\text { adhesion } \\
\text { sites }\end{array}$ & Results \\
\hline Lyell et al. [5] & Prospective cohort & $\begin{array}{l}\text { Effect of parietal peritoneal } \\
\text { closure }\end{array}$ & 173 & Over 4 sites & $\begin{array}{l}\text { Parietal peritoneal closure is associated with } \\
\text { reduced adhesion formation }\end{array}$ \\
\hline Tulandi et al. [11] & Prospective cohort & $\begin{array}{l}\text { Prevalence of adhesions } \\
\text { with or without keloids }\end{array}$ & 429 & Over 4 sites & $\begin{array}{l}\text { Women with keloids have increased adhesions } \\
\text { between the uterus and the bladder or the } \\
\text { abdominal wall }\end{array}$ \\
\hline Tulandi et al. [12] & Prospective cohort & $\begin{array}{l}\text { Prevalence and extent of } \\
\text { adhesions after repeated } \\
\text { cesareans }\end{array}$ & 1,026 & Over 4 sites & $\begin{array}{l}\text { Adhesion are mainly between the uterus and } \\
\text { the bladder or the anterior abdominal wall }\end{array}$ \\
\hline
\end{tabular}


Table 2 Randomized and prospective studies with unclear evaluation of adhesions

\begin{tabular}{|c|c|c|c|c|c|}
\hline Authors & Type of study & $\begin{array}{l}\text { Main outcome } \\
\text { measures }\end{array}$ & $\begin{array}{l}\text { Number of } \\
\text { patients } \\
\text { analyzed }\end{array}$ & Results & Comments \\
\hline Roset et al. [13] & $\begin{array}{l}\text { Randomized } \\
\text { clinical trial }\end{array}$ & $\begin{array}{l}\text { Effect of combined } \\
\text { parietal and visceral } \\
\text { peritoneum closure }\end{array}$ & 29 & $\begin{array}{l}\text { No difference in long-term } \\
\text { morbidity between } \\
\text { closure and non-closure } \\
\text { of peritoneum }\end{array}$ & $\begin{array}{l}\text { Outcomes were evaluated by patient } \\
\text { report }\end{array}$ \\
\hline Weerawetwat et al. [14] & $\begin{array}{l}\text { Randomized } \\
\text { clinical trial }\end{array}$ & $\begin{array}{l}\text { Effect of parietal and } \\
\text { visceral peritoneum } \\
\text { closure }\end{array}$ & 65 & $\begin{array}{l}\text { No difference in adhesion } \\
\text { formation between } \\
\text { closure and non-closure } \\
\text { of peritoneum }\end{array}$ & $\begin{array}{l}\text { Adhesion score (no, mild, moderate } \\
\text { and severe) based on the width of } \\
\text { the adhesion bands; lack of detailed } \\
\text { description of site-specific adhesions }\end{array}$ \\
\hline Komoto et al. [15] & $\begin{array}{l}\text { Prospective } \\
\text { cohort }\end{array}$ & $\begin{array}{l}\text { Effect of combined } \\
\text { parietal and visceral } \\
\text { peritoneum closure }\end{array}$ & 50 & $\begin{array}{l}\text { Increased adhesion } \\
\text { formation with parietal } \\
\text { and visceral peritoneum } \\
\text { closure }\end{array}$ & $\begin{array}{l}\text { Frequency of adhesions was evaluated, } \\
\text { and severity was based on whether } \\
\text { adhesiolysis was performed }\end{array}$ \\
\hline Salim et al. [16] & $\begin{array}{l}\text { Prospective } \\
\text { cohort }\end{array}$ & $\begin{array}{l}\text { Relationship between } \\
\text { abdominal scar } \\
\text { characteristics and } \\
\text { adhesions }\end{array}$ & 107 & $\begin{array}{l}\text { Depressed previous scar is } \\
\text { associated with increased } \\
\text { adhesions. }\end{array}$ & $\begin{array}{l}\text { Adhesion severity: light filmy or dense } \\
\text { vascular }\end{array}$ \\
\hline Malvasi et al. [17] & $\begin{array}{l}\text { Prospective } \\
\text { cohort }\end{array}$ & $\begin{array}{l}\text { Effect of visceral } \\
\text { peritoneum closure }\end{array}$ & 112 & $\begin{array}{l}\text { Increased adhesions with } \\
\text { visceral peritoneum } \\
\text { closure }\end{array}$ & $\begin{array}{l}\text { Evaluation of mainly adhesions } \\
\text { between the bladder and the uterus. } \\
\text { Severity of adhesions was graded } \\
\text { using the American Fertility Society } \\
\text { classification for adnexal adhesions }\end{array}$ \\
\hline Zareian et al. [18] & $\begin{array}{l}\text { Randomized } \\
\text { clinical trial }\end{array}$ & $\begin{array}{l}\text { Effect of combined } \\
\text { parietal and visceral } \\
\text { peritoneum closure }\end{array}$ & 31 & $\begin{array}{l}\text { Parietal and visceral } \\
\text { peritoneum closure may } \\
\text { decrease adhesion } \\
\text { formation }\end{array}$ & $\begin{array}{l}\text { Adhesion score based on the ease of } \\
\text { removal of adhesion bands between } \\
\text { the uterus and omentum or rectus } \\
\text { muscle. Small number of cases }\end{array}$ \\
\hline
\end{tabular}

indicate which viscera are involved in most of the adhesions. Others used the Bristow and Montz scoring system [26], a non-site-specific scoring system that has been used to evaluate adhesions after oncologic surgery as well as in an animal model. It consists of no adhesions ( 0 point), avascular adhesions ( 1 point), vascular adhesions (3 points), and thick adhesions (5 points). Some studies have not reported overall adhesions; rather, they stratified adhesions into minor or dense adhesions.

The need for a standardized adhesion classification is obvious. It will allow investigators and readers to evaluate and compare results from different studies. Routine use of a standardized adhesion classification might also enable future investigators to conduct more reproducible retrospective studies. More importantly, knowledge of the presence and severity of adhesions will prepare the obstetrician for future repeat cesarean deliveries. We and others found that rates of dense adhesion after one cesarean was greater than $20 \%$ and after two cesareans, greater than $40 \%$ [4, 27$]$.

We propose a classification of intra-abdominal adhesions after cesarean delivery. Our proposed classification is based on our previous prospective studies of adhesions after cesareans, site-specific, and assessed the severity and consistency of adhesions. We also use a point system (Table 5). Because vascularity especially at the time of repeat cesarean delivery is difficult to evaluate, we did not include it in our classification system. The application and results of using this classification system remain to be seen.

Table 3 Retrospective studies with site-specific adhesion scoring system

\begin{tabular}{|c|c|c|c|c|}
\hline Authors & Type of study & Main outcome measures & Number of patients analyzed & Results \\
\hline Morales et al. [6] & Retrospective cohort & $\begin{array}{l}\text { Prevalence of adhesions } \\
\text { after cesareans }\end{array}$ & 542 & $\begin{array}{l}\text { Cesareans result in adhesion formation. } \\
\text { Site-specific locations available only if } \\
\text { described in operative notes }\end{array}$ \\
\hline Tulandi et al. [4] & Retrospective cohort & $\begin{array}{r}\text { Prevalence of adhesion } \\
\text { after repeat cesareans }\end{array}$ & 1,283 & $\begin{array}{l}\text { Increased adhesion with each subsequent } \\
\text { cesarean. Site-specific locations available } \\
\text { only if described in operative notes. Scores } \\
\text { assigned based on severity of adhesion }\end{array}$ \\
\hline
\end{tabular}


Table 4 Retrospective studies with no or unclear description of site-specific adhesions

\begin{tabular}{|c|c|c|c|c|}
\hline Authors & Type of study & Main outcome measures & $\begin{array}{l}\text { Number of } \\
\text { patients } \\
\text { analyzed }\end{array}$ & Results \\
\hline Myers and Bennett [19] & Retrospective study & $\begin{array}{l}\text { Effect of combined parietal and } \\
\text { visceral peritoneum closure }\end{array}$ & 191 & $\begin{array}{l}\text { Combined parietal and visceral peritoneum } \\
\text { closure was associated with decreased } \\
\text { adhesion formation }\end{array}$ \\
\hline Phipps et al. [20] & Case control study & $\begin{array}{l}\text { Identification of risk factor of } \\
\text { bladder injury }\end{array}$ & 126 & $\begin{array}{l}\text { Adhesions from prior cesarean is a risk } \\
\text { factor for bladder injury at repeat cesarean }\end{array}$ \\
\hline Zhu et al. [21] & Retrospective cohort & $\begin{array}{l}\text { Effect of parietal peritoneum } \\
\text { closure }\end{array}$ & 612 & $\begin{array}{l}\text { Non-closure of parietal peritoneum is } \\
\text { associated with increased visceral adhesions }\end{array}$ \\
\hline Nisenblat et al. [22] & Retrospective cohort & $\begin{array}{l}\text { Complications after repeated } \\
\text { cesareans }\end{array}$ & 768 & $\begin{array}{l}\text { Increased complications and dense adhesion } \\
\text { with cesarean number. Dense adhesions } \\
\text { were defined as multiple adhesions between } \\
\text { the uterus and surrounding organs }\end{array}$ \\
\hline Hamel [23] & Retrospective cohort & $\begin{array}{l}\text { Incidence and severity of } \\
\text { adhesions }\end{array}$ & 62 & $\begin{array}{l}\text { Decreased adhesions with closure of the rectus } \\
\text { muscle or the parietal peritoneum. }\end{array}$ \\
\hline Fatusic and Hudic [24] & Retrospective study & Prevalence of adhesions & 400 & $\begin{array}{l}\text { Decreased adhesions after MisgavLadach } \\
\text { cesarean. Adhesion scores based on Bristow } \\
\text { and Montz scoring system }\end{array}$ \\
\hline Chapa et al. [25] & Retrospective cohort & $\begin{array}{l}\text { Effect of adhesion barriers at } \\
\text { cesarean }\end{array}$ & 112 & $\begin{array}{l}\text { An adhesion barrier and parietal peritoneum } \\
\text { closure reduced adhesion formation }\end{array}$ \\
\hline
\end{tabular}

The characteristics of the previous incision scar might provide an idea about the severity of intra-abdominal adhesions $[11,28]$. In a study, the authors reported that elevated scars are associated with increased dense adhesions [28]. In another study, women with keloids on the cesarean scar have increased adhesions between the uterus and the bladder, and between the uterus and the abdominal wall [11]. A uniform reporting of adhesions at the time of previous cesareans will be very useful.

Indeed, adhesions after a cesarean delivery are common, and their extent and density increase with repeated cesarean deliveries. The presence of adhesions increases time to delivery of the fetus and time of the procedure $[4,11,29]$. Greenberg et al. reported that the mean interval of incision to delivery in women with severe adhesions (19.8 $\mathrm{min})$ was significantly longer than in those with less severe adhesions (15.6 min). In addition, more women with severe adhesions remained undelivered at $30 \mathrm{~min}$ after incision [29]. Maternal morbidities can also increase with each subsequent cesarean delivery. This includes increased bowel and bladder injury, uterine and wound dehiscence, hysterectomy, post-partum hemorrhage, and pulmonary emboli $[4,30,31]$.

\section{Conclusion}

We hereby outlined the first standardized classification of adhesions after cesarean delivery. It is site-specific and evaluates the prevalence and severity of adhesions. We encourage clinicians and investigators to adopt this classification into a standard practice.
Table 5 Proposed classification of intra-abdominal adhesions after cesarean delivery

\begin{tabular}{|c|c|c|c|c|}
\hline Adhesions & Consistency of the adhesions & $<3 \mathrm{~cm}$ & $3-6 \mathrm{~cm}$ & $>6 \mathrm{~cm}$ \\
\hline \multirow[t]{2}{*}{ Between uterus and bladder } & Filmy & 1 & 2 & 4 \\
\hline & Dense & 4 & 8 & 16 \\
\hline \multirow[t]{2}{*}{ Between uterus and abdominal fascia } & Filmy & 1 & 2 & 4 \\
\hline & Dense & 4 & 8 & 16 \\
\hline \multirow[t]{2}{*}{ Between uterus and omentum } & Filmy & 1 & 2 & 4 \\
\hline & Dense & 4 & 8 & 16 \\
\hline \multirow[t]{2}{*}{ Between omentum and abdominal fascia } & Filmy & & 2 & \\
\hline & Dense & & 8 & \\
\hline \multirow{2}{*}{$\begin{array}{l}\text { Adhesions to other pelvic structure that } \\
\text { interfere with the delivery }\end{array}$} & Filmy & & 4 & \\
\hline & Dense & & 8 & \\
\hline
\end{tabular}


Acknowledgments Togas Tulandi received a travel grant as advisor for Genzyme for adhesion related research.

\section{References}

1. Hamilton BE, Ventura SJ, Osterman MJK, Kirmeyer S, Mathews TJ, Wilson E (2011) Births: final data for 2009. Nat Vital Stat Rep 60:1-35

2. Martin JA, Hamilton BE, Ventura SJ et al. Births: Final data for 2003. National vital statistics reports; vol 54 no 2. Hyattsville, MD. National Center for Health Statistics. 2005. http://www.cdc.gov/ nchs/births.htm

3. Barber EL, Lundsberg LS, Belanger K, Pettker CM, Funai EF, Illuzzi JL (2011) Indications contributing to the increasing cesarean delivery rate. Obstet Gynecol 118:29-38

4. Tulandi T, Agdi M, Zarei A, Miner L, Sikirica V (2009) Adhesion formation and morbidity after repeat cesarean delivery. Am J Obstet Gynecol 201:56.e.1-56.e.16

5. Lyell DJ, Caughey AB, Hu E, Daniels K (2005) Peritoneal closure at primary cesarean delivery and adhesions. Obstet Gynecol $106: 275-280$

6. Morales KJ, Gordon MC, Bates GW Jr (2007) Postcesarean delivery adhesions associated with delayed delivery of infant. Am J Obstet Gynecol 196:461.e1-461.e16.8

7. Nisenblat V, Barak S, Griness OB, Degani S, Ohel G, Gonen R (2006) Maternal complications associated with multiple cesarean deliveries. Obstet Gynecol 108:21-26

8. Makoha FW, Felimban HM, Fathuddien MA, Roomi F, Ghabra T (2004) Multiple cesarean section morbidity. Int J Gynecol Obstet 87:227-232

9. American Fertility Society (1988) The American Fertility Society classifications of adnexal adhesions, distal tubal occlusion, tubal occlusion secondary to tubal ligation, tubal pregnancies, müllerian anomalies and intrauterine adhesions. Fertil Steril 49:944-955

10. Diamond MP (2011) Postoperative adhesions: an underappreciated complication of cesarean deliveries. Am J Obstet Gynecol 205(6 Suppl):S1

11. Tulandi T, Al-Sannan B, Akbar G, Ziegler C, Miner L (2011) Prospective study of intraabdominal adhesions among women of different races with or without keloids. Am J Obstet Gynecol 204:132.e1-132.e14

12. Tulandi T, Al-Sannan B, Akbar G, Miner L, Ziegler C, Sikirica V (2011) Clinical Relevance of intra-abdominal adhesions in cesarean delivery. Gynecol Surg 8(4):399-403

13. Roset E, Boulvain M, Irion O (2003) Nonclosure of the peritoneum during caesarean section: long-term follow-up of a randomised controlled trial. Eur J Obstet Gynecol Reprod Biol 108:40-44

14. Weerawetwat W, Buranawanich S, Kanawong M (2004) Closure vs. non-closure of the visceral and parietal peritoneum at cesarean delivery: 16 year study. J Med Assoc Thail 87:1007-1011

15. Komoto Y, Shimoya K, Shimizu T, Kimura T, Hayashi S, TemmaAsano K, Kanagawa T, Fukuda H, Murata Y (2006) Prospective study of non-closure or closure of the peritoneum at cesarean delivery in 124 women: impact of prior peritoneal closure at primary cesarean on the interval time between first cesarean section and the next pregnancy and significant adhesion at second cesarean. J Obstet Gynaecol Res 32:396-402

16. Salim R, Kadan Y, Nachum Z, Edelstein S, Shalev E (2008) Abdominal scar characteristics as a predictor of intra-abdominal adhesions at repeat cesarean delivery. Fertil Steril 90:2324-2327

17. Malvasi A, Tinelli A, Farine D, Rahimi S, Cavallotti C, Vergara D, Martignago R, Stark M (2009) Effects of visceral peritoneal closure on scar formation at cesarean delivery. Int J Gynaecol Obstet 105:131-135

18. Zareian Z, Zareian P (2006) Non-closure versus closure of peritoneum during cesarean section: a randomized study. Eur J Obstet Gynecol Reprod Biol 128:267-269

19. Myers SA, Bennett TL (2005) Incidence of significant adhesions at repeat cesarean section and the relationship to method of prior peritoneal closure. J Reprod Med 50:659-662

20. Phipps MG, Watabe B, Clemons JL, Weitzen S, Myers DL (2005) Risk factors for bladder injury during cesarean delivery. Obstet Gynecol 105:156-160

21. Zhu Y, Cai Q, Wu W (2006) Closure vs. nonclosure of the peritoneum at cesarean delivery. Int J Gynaecol Obstet 94:103-107

22. Nisenblat V, Barak S, Griness OB, Degani S, Ohel G, Gonen R (2006) Maternal complications associated with multiple cesarean deliveries. Obstet Gynecol 108:21-26

23. Hamel KJ (2007) Incidence of adhesions at repeat cesarean delivery. Am J Obstet Gynecol 196:e31-e32

24. Fatusic Z, Hudic I (2009) Incidence of post-operative adhesions following Misgav-Ladach cesarean section - a comparative study. J Matern Fetal Neonatal Med 22:157-160

25. Chapa HO, Venegas G, Vanduyne CP, Antonetti AG, Sandate JP, Silver L (2011) Peritoneal adhesion prevention at cesarean section: an analysis of the effectiveness of an absorbable adhesion barrier. J Reprod Med 56:103-109

26. Bristow RE, Montz FJ (2005) Prevention of adhesions formation after radical oophorectomy using a sodium hyaluronatecarboxymethylcellulose (HA-CMC) barrier. Gynecol Oncol 99:301-308

27. Soltan MH (1996) Al Nuaim L, Khashoggi T, Chowdhury N, Kangave D, Adelusi B. Sequelae of repeat cesarean sections. Int J Gynaecol Obstet 52:127-132

28. Dogan NU, Haktankacmaz SA, Dogan S, Ozkan O, Celik H, Eryilmaz OG, Doganay M, Gulerman C (2011) A reliable way to predict intraabdominal adhesions at repeat cesarean delivery: scar characteristics. Acta Obstet Gynecol Scand 90:531-534

29. Greenberg MB, Daniels K, Blumenfeld YJ, Caughey AB, Lyell DJ (2011) Do adhesions at repeat cesarean delay delivery of the newborn? Am J Obstet Gynecol 205:380.e1-380.e15

30. Silver RM, Landon MB, Rouse DJ, Leveno KJ, Spong CY, Thom EA, Moawad AH (2006) Caritiset al. Maternal morbidity associated with multiple repeat cesarean deliveries. Obstet Gynecol 107:1226-1232

31. Andolf E, Thorsell M, Kallen K (2010) Cesarean delivery and risk for postoperative adhesions and intestinal obstruction: a nested case-control study of the Swedish Medical Birth Registry. Am J Obstet Gynecol 203:406.e1-406.e16 